\title{
Stock Control in Automotive Industry with Simulation Utilization'
}

\section{Summary}

At this time in economic environment there is the big trend of coming logistical chain, supply chain and supply chain management (SCM). SCM deals with material and information flows control, inventory management, demand forecast, production plan optimalization, distribution management etc. Nowadays for effective purchase, production and distribution plan and control in companies are utilized the simulation and simulation programmes. This paper deals with the simulation programme Witness and its utilization for finding of results real problems - simulation utilization for stocks solution in automotive industry. The model can be used for the determination of new delivery system of materials and for stocks reduction.

\section{Introduction}

Bringing changes in practice always involves inconsiderable risks, the dynamic simulation as a predictive method helps in minimizing the risks by modelling your work environment and simulating the results of different decisions. By the means of the running model it is possible to test the alternative behaviour of the observed object under different conditions and with an aim to defined scales of productivity we focus on optimizing its functions. Such modelled object or process can be e.g. running production, assembling line, machine, other sites and technological devices and their sequences, silo, operational stocks of store and manipulation, information flow, etc.

\footnotetext{
${ }^{*}$ Mgr, Department of Economics and Management of Chemical and Food Industry, Institute of Chemical Technology Prague, Czechy.

${ }^{1}$ This article is published as a part of research intention MSM 6046137306.
} 
This way of work brings many advantages - it is possible to create models of yet not existing systems and suggest solutions that behave exactly according to the demand of the submitter. The simulation time passes faster than in real, so it is possible to promptly evaluate different variants of suggested solutions.

This article describes the simulation method, its utilization in automotive industry. This problem is concerned stock solution in company where are produced semi finished products for final production of automobile.

\section{Simulation}

One of characteristics of classic models is their static. On the basis of model's result was accepted one - off decisions on the beforetime. In practice we need to catch dynamic of control system. One of used method is dynamic programming. But by experiment of implementation of accidental influence to model of dynamic programming we get at next increase of numerical calculations.

Extraordinarily efficient tool, how overcome above problems, is computing simulation. The simulation is process of the production logical - mathematical model of real object, defined system of the model or decision process and realization of quantity experiments with the model.

The target is (Gros, 2003):

- Describe of the system.

- Knowledge of its functions.

- Presumption of its behaviour in future.

- Finding the solution of problem.

- Suggestion and verification of functions in new structure.

The simulation model is considered for the system that copies the structure of system and its transaction by the help of the realisation of the simulation programme in computer. The system simulation is specific form of realization process that is used as the tool and the method of real and suggested system investigation, support of decision-making process, the tool for formulation of pieces of knowledge, hypotheses and prognoses. The subject of simulation system is system defined as the objects realization and their transaction that is dynamic systems. The basic principle of system simulation is to understand opinions about the simulation system by the help of experimentations with the simulation model (Chovanec, 2006).

Shannon defined the simulation as it is process of creation model of real system and diversion of experiments with this model in order to achievement of better understanding of studied system behaviour or in order to appraisal of (Ferenčíková, Bigoš, 2006).

Since the 1950s computer simulation has been used to tackle a range of business problems leading to s sectors, including manufacturing and service industries as well as the public sector (Robinson, 2001). 


\section{Simulation programme}

\section{WITNESS}

This programme is characterized as the one of most successful simulation products for the simulation of production, frontage and logistical processes. About this programme I write in the next chapter.

2. eM-Plant

Programme eM-Plant enables the discreet simulation of production and logistical processes. The rapid construction of model, the presentation of model in virtual reality, "on-line" changes, access to Internet, compatibleness with Microsoft Office and the other products - that is advantages of eM-Plant.

3. QUEST

It introduces the complete 3D digital product for the simulation, analysis and cost-effectiveness of processes in company. From 3D model is possible to determine the optimal layout of machines, production time and flow of costs in existing or new systems.

4. Mantra4D

Mantra 4D is open graphic programme that is qualified to import from the other graphic systems (AutoCAD, Microstation etc.) 3D forms. The programme offers possibilities of formation the library of $3 \mathrm{D}$ forms and after addition actions machine and labour are become dynamic element. These elements are used in other simulation programme, for example Witness, eM-Plant etc.

5. SiMPLE++

This name of programme introduces SiMulation in Production, Logistics and Engineering. The programme is the standard software for graphic and integrated modelling, simulation and animation. It is programming in language $\mathrm{C}++$. The big advantage is its openness capability of change data with the different type of databases even during the simulation.

\section{Simulation programme Witness}

Nowadays there are available simulation programmes that enable the description and modelling of the real systems behaviour on the market. WITNESS has been used as the environment for my simulation. WITNESS, the world's leading business simulation system, gives you the power and flexibility to model your working environment, simulate the implications of different business decisions and understand any process, however complex. As a result, you can always be confident that you have found the best business solution for organization-efore making a financial commitment to change.

WITNESS is the most successful program for simulation of production, service and logistic system on the world. It ems, creation of centralized optimization modulus and 3D visualization - virtual reality (Ferenčíková, Bigoš, 2006).

This programme falls into the group of visual simulation programmes, when the model is seen on screen all the time. Each worker can observe the behaviour of each individual element every minute. WITNESS can be used for analysis of any process and all incidents are recorded for assessment of system performance according to selected 
criteria. In the programme the formulation of models that truly describe real environment is possible. At any time I can stop the simulation, change system parameters (for example capacity of buffer, number of labour on the shift, number of machines or buffers) and then I can continue with simulation. The incidences of these changes can be seen immediately.

\section{Model of stocks solution}

The model describes assembly line producing goods that are semi finished products for final assembly of automobile in other company. Assembly line consists to three station - riveting, preassembly and control. The operation of riveting represents two machines which work concurrently. Each machine operates one worker. The second of station is preassembly that is compacted of two operation positions that are concurred. Each position is operated worker accordingly in the model; each position is created as machine. Semi finished products from riveting and preassembly are sent to worker that brings two semi finished products together. This worker is created as machine in the model. Next worker put the product to the machine - control. The final product is compiled from sixteen materials $\mathrm{S} 1-\mathrm{S} 16$.

The model involves the material flows from material entries for production, their stocking and stocks of semi finished products from own production. The target of this model is to analyze the material flow front of input to the production and to verify the usefulness and effectiveness of current material ordering system for final product.

Materials S6, S11, S15 and S16 are produced in this company accordingly their delivery system is very simply. The other materials are imported from supplier. And this delivery system is problem for this model.

Each material has its small buffer at assembly line - in model this buffer is called $\mathrm{H} \_$buffer. If this buffer is full and material is delivered then worker puts material in buffer, in W buffer. For this material flow is accepted system FIFO (first in, first out). That means if material is delivered, $\mathrm{H}$ buffer is empty and in $\mathrm{W}$ buffer is stock of this material, than in $\mathrm{H}_{-}$buffer is transported material from $\mathrm{W}_{-}$buffer and the new material is put into W_buffer.

The results of this model will be various combinations of delivery time providing cost minimization. In this model are used costs of material entry, costs of package transport, costs of material transport between $\mathrm{H} \_$buffer and $\mathrm{W} \_$buffer, costs of stocking material etc.

For this result it is possible to use the specific tool of programme Witness - optimiser. It finds the best result according to criteria function and defined conditions. Criteria function will be total costs connected with storage and gathering a stock.

On the Figure 1 you can see the model of stock solution in automotive industry.

This model is possible to use for the determination of bottleneck of this assembly line. For this establishment I use one of the numbers of outputs - the chart of utilization of single machine in production. The highest value of state "Busy" has the machine "preassembly2". 
Fig. 1. Model of stock solution in automotive industry

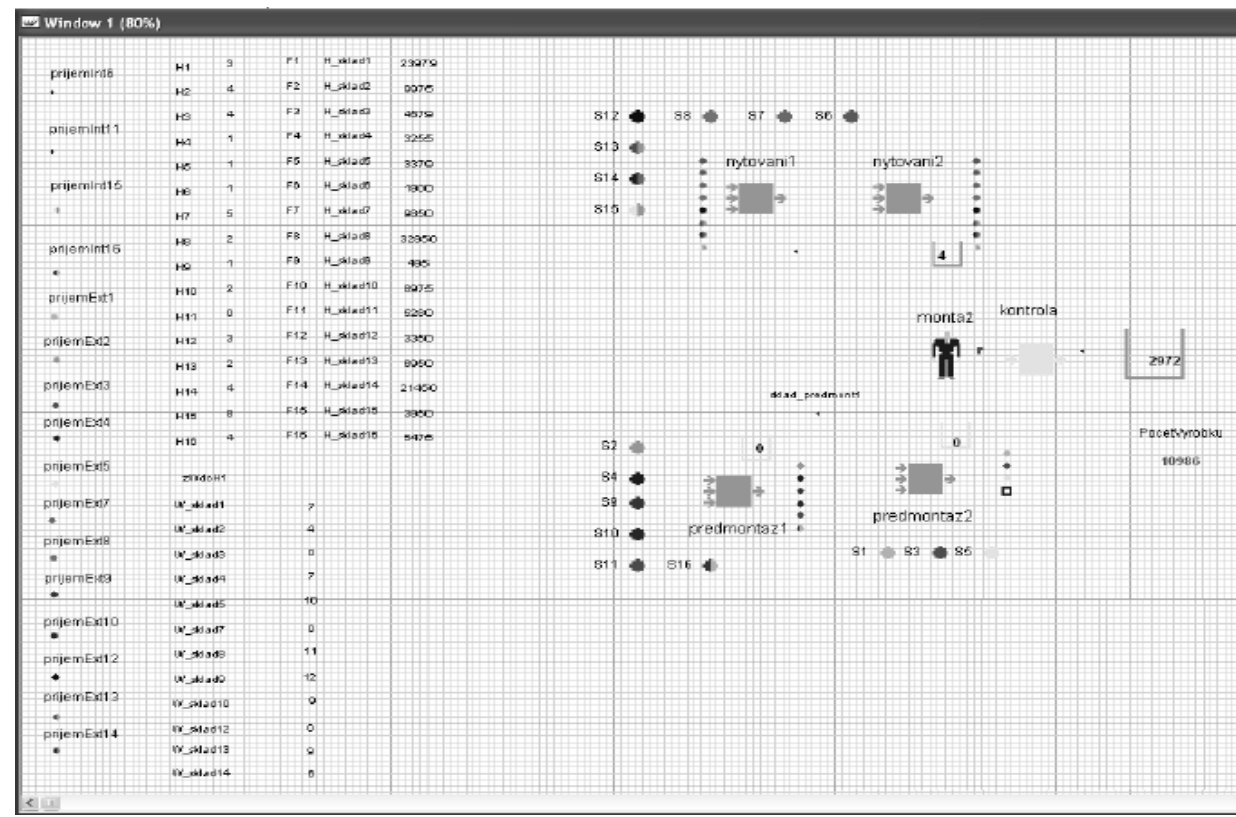

\section{Conclusion}

At the present time it is very important to effective control material and information flows in company and in all supply chain. For effective control are used dynamic simulations. On the market it is possible to buy various simulation programmes. On our Department of Economics and Management of Chemical and Food Industry is utilized programme Witness. This programme falls into the group of visual simulation programmes, when the model is seen on screen all the time. Each worker can observe the behaviour of each individual element every minute. The aim of this article was to obtain the information about simulation utilization for assembly line in automotive industry. The built-up model serves for the determination of bottleneck and for effective material flow control on the start of production. The target of the model is established the optimum delivery time system for the individual materials providing cost minimization and satisfaction of all customer's requirements in demanded time. This article is published as a part of research intention MSM 6046137306.

\section{References}

Ferenčíková M., Bigoš P., Simulácia jako nástroj na riešenie problémov programom Witness, „Transfer inovácií, 2006, no. 9 (in Slovak). 
Gros I., Kvantitativní metody v manažerském rozhodování, Praha 2003 (in Czech).

Chovanec A., Modelovanie a simulácia diskrétných stochastických procesov, Trnavská Univerzita, 2005, skriptum (in Slovak).

Robinson S., Successful Simulation - A Practical Approach to Simulation Projects, McGraw-Hill Co., 2001.

\section{Kontrola zapasów w przemyśle samochodowym z wykorzystaniem metody symulacji}

\section{Streszczenie}

W otoczeniu ekonomicznym zachodza wspótcześnie znaczne zmiany w zakresie logistyki. Powszechnie stosowana jest koncepcja zarzqdzania łańcuchem dostaw. Wykorzystywana jest ona do kontroli przeplywu towarów, materiatów i informacji, prognozowania popytu, optymalizacji planów produkcji, dystrybucji wyrobów itd. Wymaga odpowiedniego oprzyrzqdowania, głównie wykorzystania narzędzi i programów symulacyjnych. Artykut przedstawia model symulacji w zakresie zarzadzania zapasami w przedsiębiorstwach sektora samochodowego. Prezentowana metoda może być wykorzystana do stworzenia nowego systemu dostaw materiałów i minimalizowania stanu ich zapasów. 